\title{
Expression of metalloprotease insulin-degrading enzyme insulysin in normal and malignant human tissues
}

\author{
CHRISTINA YFANTI ${ }^{1}$, KARIN MENGELE ${ }^{1}$, APOSTOLOS GKAZEPIS ${ }^{1}$, GREGOR WEIRICH $^{2}$, \\ CECYLIA GIERSIG $^{3}$, WEN-LIANG KUO ${ }^{4}$, WEI-JEN TANG ${ }^{4}$, MARSHA ROSNER $^{4}$ and MANFRED SCHMITT ${ }^{1}$ \\ ${ }^{1}$ Clinical Research Unit, Department of Obstetrics and Gynecology and ${ }^{2}$ Institute of Pathology, Klinikum rechts der Isar, \\ Technical University of Munich, Ismaninger Str. 22, D-81675 Munich; ${ }^{3}$ Federal Institute for Drugs and Medical Devices, \\ Kurt-Georg-Kiesinger-Allee 3, D-53175 Bonn, Germany; ${ }^{4}$ Ben May Institute for Cancer Research, \\ Center for Integrative Sciences, 929 East 57th Street, W421, Chicago, IL 60637, USA
}

Received May 2, 2008; Accepted June 30, 2008

DOI: 10.3892/ijmm_00000038

\begin{abstract}
Insulin-degrading enzyme (IDE, insulysin, insulinase; EC 3.4.22.11), a thiol metalloendopeptidase, is involved in intracellular degradation of insulin, thereby inhibiting its translocation and accumulation to the nucleus. Recently, protein expression of IDE has been demonstrated in the epithelial ducts of normal breast and breast cancer tissue. Utilizing four different antibodies generated against different epitopes of the IDE molecule, we performed Western blot analysis and immunohistochemical staining on several normal human tissues, on a plethora of tumor cell lines of different tissue origin, and on malignant breast and ovarian tissue. Applying the four IDE-directed antibodies, we demonstrated IDE expression at the protein level, by means of immunoblotting and immunocytochemistry, in each of the tumor cell lines analyzed. Insulin-degrading enzyme protein expression was found in normal tissues of the kidney, liver, lung, brain, breast and skeletal muscle, as well as in breast and ovarian cancer tissues. Immunohistochemical visualization of IDE indicated cytoplasmic localization of IDE in each of the cell lines and tissues assessed. In conclusion, we performed for the first time a wide-ranging survey on IDE protein expression in normal and malignant tissues and cells thus extending our knowledge on the cellular and tissue distribution of IDE, an enzyme which to date has mainly been studied in connection with Alzheimer's disease and diabetes but not in cancer.
\end{abstract}

Correspondence to: Dr Manfred Schmitt, Clinical Research Unit, Department of Obstetrics and Gynecology, Klinikum rechts der Isar, Technische Universitaet Muenchen, Ismaninger Str. 22, D-81675 Munich, Germany

E-mail: manfred.schmitt@lrz.tum.de

Key words: insulin-degrading enzyme, tumor cell lines, normal human tissues, breast cancer, ovarian cancer

\section{Introduction}

Insulin's major effect on protein metabolism is the inhibition of protein degradation. This is via inhibition of proteasome activity through interaction with insulin-degrading enzyme (IDE) (1). IDE (insulysin, insulinase; EC 3.4.22.11, MW110 kDa; M16.002) is a highly conserved, neutral zincand thiol-dependent metallopeptidase. It belongs to the M16 (pitrilysin) family of zinc-metalloendopeptidases, namely inverzincins, characterized by the inverted zinc binding motif HXXEH (2). IDE is present in human beings, animals, fungi, and plants (2-4; http://merops.sanger.ac.uk/, see distribution within family M16.002: insulysin) and is reported to be expressed in the liver, adipocytes, muscle cells, erythrocytes, and kidney (3-5) but also in cell types not responsive to insulin (6) (www.genecards.org/cgi-bin/carddisp.pl?gene=IDE). Despite its predominant presence in the cytosol, IDE is also found in small but significant amounts in subcellular compartments such as the plasma membrane, endosomes, peroxisomes, and mitochondria (7-15).

IDE exhibits a preference for basic (arginine, lysine) or bulky hydrophobic residues (phenylalanine, leucine, tyrosine) at the P1 site of the target protein (16). This preference for cleavage at hydrophobic and basic residues supports the assumption that substrate recognition by IDE rather depends on the tertiary peptide conformation than on the amino acid sequence (17).

IDE is reported to cleave small proteins of diverse sequences, several of which have a common ability to form $ß$-pleated sheet-rich amyloid fibrils, i.e. insulin, amyloid $\beta$ protein, amylin, glucagon, atrial natriuretic factor, and calcitonin (16-20). However, IDE is also known to be a significant enzyme responsible for the degradation of insulinlike growth factors I and II (21) and transforming growth factor $\alpha(22,23)$. IDE knockout mice show significantly elevated levels of blood insulin, brain $\beta$-amyloid, and brain amyloid-precursor protein intracellular domain, providing key in vivo evidence that IDE degrades extracellular and intracellular peptides (24).

Conducting its proteolytic activity, IDE regulates translocation of insulin from the cytoplasm to the nucleus 
(25), preventing insulin from binding to and inactivating the nuclear tumor suppressor retinoblastoma protein (RB) (26).

Based on this previous notion, implying an underlying role of IDE in diabetes $(27,28)$, Alzheimer's disease (29) and tumor progression, and refering to the recently published data of Radulescu et al (30) presenting immunohistochemical expression of IDE in normal and malignant human breast tissue, we extended our study on the analysis of IDE expression in various normal tissues, in breast and ovarian cancer tissues, and in tumor cell lines of different tissue origin. We used immunohistochemistry and Western blotting, employing various antibodies generated against different epitopes of IDE.

\section{Materials and methods}

Tumor cell lines. The following human cell lines, cultivated in DMEM-10\% fetal calf serum- $0.2 \%$ arginine/asparagine/ $1 \%$ HEPES, were used in the study: CAL 27, squamous cell carcinoma of the tongue, (German Collection of Microorganisms and Cell Cultures, DSMZ, Braunschweig, Germany); FaDu, esophageal squamous cell carcinoma of the hypopharynx (M. Baumann, Dresden); OVMZ-6, epithelial ovarian cancer (V. Moebus, Frankfurt, Germany); HeLa, epithelial cervical cancer, ATCC-CCL-2 [American Type Culture Collection (ATCC), Manassas, VA, USA]; Caco-2, epithelial colon adenocarcinoma, ATCC-HTB-37 (K.P. Janssen, Munich); HT-1080, fibrosarcoma, ATCC-CCL-121 (ATCC) and HaCaT, spontaneously transformed keratinocyte cell line (M. Kotzsch, Dresden, Germany). The following cell lines were cultivated in RPMI-10\% fetal calf serum-1\% glutamine: U-937, myelomonocytic histiocytic lymphoma cell line, ATCC-CRL-1593.2 (ATCC) and SK-BR-3, epithelial breast adenocarcinoma of metastatic origin, pleural effusion, ATCC-HTB-30 (ATCC).

Tissue microarray construction. The following formalinfixed, buffered, paraffin-embedded tissues obtained from adult human individuals were selected at random from the archives of the Institute of Pathology, Technical University, Munich: skeletal muscle, lung, brain, liver, kidney, and breast. Tissue microarrays were prepared using a 1-mm punch core needle instrument (MTA I Personal Tissue Arrayer, Beecher Instruments, USA) as described (31). In order to compensate for individual differences in tissue heterogeneity and staining intensity, specimens from three different individuals were sampled per organ.

Cell microarray construction. Cultured cells $\left(3 \times 10^{7}\right)$ were washed twice in $3 \mathrm{ml}$ phosphate-buffered saline (PBS) $\left(20^{\circ} \mathrm{C}\right)$ and centrifuged $\left(300 \times \mathrm{g}, 5 \mathrm{~min}, 20^{\circ} \mathrm{C}\right)$. Then the cell pellet was re-suspended in $5 \mathrm{ml}$ of $10 \%$ formalin in PBS (30 $\left.\mathrm{min}, 20^{\circ} \mathrm{C}\right)$, centrifuged $\left(800 \mathrm{x} \mathrm{g}, 5 \mathrm{~min}, 20^{\circ} \mathrm{C}\right)$, washed with Tris-buffered saline (TBS, $20^{\circ} \mathrm{C}$ ), additionally washed in PBS and then centrifuged again. Subsequently, $150 \mu 1$ thrombin $\left(10 \mathrm{U} / \mathrm{ml} \mathrm{H}_{2} \mathrm{O}_{\text {dist }}\right.$; Sigma-Aldrich, Taufkirchen, Germany) $750 \mu \mathrm{l}$ casein (Sigma-Aldrich; $10 \mathrm{mg} / \mathrm{ml} 0.04 \mathrm{M}$ Tris- $\mathrm{HCl}, \mathrm{pH} 8.0)$ and $600 \mu \mathrm{l}$ fibrinogen $\left(25 \mathrm{mg} / \mathrm{ml} \mathrm{H}_{2} \mathrm{O}_{\text {dist }}\right)$ were added to the cell pellet and left overnight at $4{ }^{\circ} \mathrm{C}$ to solidify before paraffin-embedding. Since cells were formalin-fixed and paraffin-embedded, the procedure for construction of the CMAs was identical to the way tissue microarrays are prepared (31).

Cell and tissue extracts. Cell extracts were prepared by lysing the cells with the non-ionic detergent Triton X-100 $\left(1 \% \mathrm{w} / \mathrm{v}\right.$ in $\left.\mathrm{TBS}, 12 \mathrm{~h}, 4^{\circ} \mathrm{C}\right)$, and the supernatant containing the IDE protein was harvested by high-speed centrifugation $\left(25,000 \times \mathrm{g}, 10 \mathrm{~min}, 4^{\circ} \mathrm{C}\right)$. For the preparation of tissue extracts, freshly frozen tissue specimens, after being stored in liquid nitrogen, were pulverized in their frozen state using the Mikro-Dismembrator S laboratory ball mill (Sartorius, Göttingen, Germany). The powder was then subjected to $1 \%$ Triton X-100 (1\% w/v in TBS; $\left.12 \mathrm{~h}, 4^{\circ} \mathrm{C}\right)$ for protein extraction, followed by high-speed centrifugation (32). Extracts were aliquoted and stored in liquid nitrogen for further use.

Immunoblotting analysis of recombinant and cellular IDE. Cell line extracts $(20 \mu \mathrm{g} / \mathrm{lane})$ and tissue extracts $(25 \mu \mathrm{g} / \mathrm{lane})$ as well as recombinant ${ }^{6} \mathrm{His}$-tagged IDE (20 ng/lane) [Fig. 1, generated by Dr W. Tang, Ben May Institute for Cancer Research, Center for Integrative Sciences, Chicago, IL, USA (33)], were heated and reduced $\left(5 \mathrm{~min}, 95^{\circ} \mathrm{C}\right)$ in the presence of 2\% (w/v) SDS and 5\% (v/v) 2-mercaptoethanol. Samples were immediately subjected to electrophoresis on $10 \%$ SDSpolyacrylamide gels and separated proteins were transferred onto a polyvinylidene fluoride membrane, PVDF, (Pall, Dreieich, Germany), $3 \mathrm{~h}$ at $75 \mathrm{~mA} /$ membrane, applying a semi-dry transfer device (Whatman Biometra, Göttingen, Germany). After transfer, membranes were blocked with 5\% skimmed milk powder in PBS-0.1\% Tween-20 (pH 7.4, $1 \mathrm{~h}$, RT). Subsequently, blots were incubated overnight at $4^{\circ} \mathrm{C}$ with four different primary antibodies diluted in incubation buffer (Table I), and then washed three times (10 min, RT) with PBS-0.1\% Tween-20. Antigen-antibody complexes were visualized using HRP-conjugated goat anti-rabbit IgG (Jackson ImmunoResearch, \#111-035-003) or HRPconjugated rabbit anti-mouse IgG (Dianova, \#315-035-045), diluted 1:10,000 in 5\% skimmed milk powder in PBS-0.1\% Tween-20. This was followed by a chemiluminescent reaction (ECL, Amersham Biosciences, Little Chalfont, UK). For assessment of the relative molecular mass of the separated proteins, a pre-stained Protein IV-Marker set (PeqLab, Erlangen, Germany) was used. Glyceraldehyde-3-phosphate dehydrogenase (GAPDH) was used as an internal control. The same blots were incubated with mouse anti-GAPDH (\#MAB374, Chemicon, Billerica, MA, USA), after stripping the membranes in $1.5 \% \mathrm{w} / \mathrm{v}$ glycine, $0.1 \% \mathrm{w} / \mathrm{v}$ SDS, and $1 \%$ Tween-20, $\mathrm{pH} 2.2$, for $1 \mathrm{~h}$ at RT.

Immunohistochemical analysis of IDE in human tissues and tumor cell lines. For immunohistochemical analysis, tissue microarray sections and cell microarray sections ( $2 \mu \mathrm{m}$ thick) were deparaffinized and rehydrated by being passed through xylene twice (10 min), and then through a descending series of graded ethanol (100, 96 and 70\%, 5 min for each step). At this point, no antigen retrieval procedure was employed. After a 5-min washing step in TBS at RT including buffer change, endogenous peroxidase activity was blocked by incubating the tissue sections with $3 \% \mathrm{H}_{2} \mathrm{O}_{2}$ (K33354110, Merck, 
Table I. Antibodies used, raised against different epitopes of insulin-degrading enzyme (IDE).

\begin{tabular}{lll}
\hline Antibody/source & \multicolumn{1}{c}{ Immunogen } & Host animal \\
\hline $\begin{array}{l}\text { UCG 43/6, } \\
\text { University of Chicago, IL, USA }(33,34)\end{array}$ & 6His-tagged full length IDE & Rabbit, polyclonal, antiserum \\
$\begin{array}{l}\text { \#MMS-282R, Covance, clone 9B12, } \\
\text { Berkley, CA, USA }\end{array}$ & IDE purified from human erythrocytes & Mouse, monoclonal IgG1, ascites \\
\#PRB-282C, Covance, lot BC-2 & Recombinant IDE-GST-fusion protein, & Rabbit, polyclonal, antiserum \\
Berkley, CA, USA & containing aa 97-273 of rat IDE \\
$\begin{array}{l}\text { Anti-IDE-p15, Pineda, } \\
\text { Berlin, Germany }\end{array}$ & $\begin{array}{l}\text { IDE-peptide p15 encompassing } \\
\text { aa 940-953 of rat IDE }\end{array}$ & $\begin{array}{l}\text { Rabbit, polyclonal; antiserum } \\
\text { purified by IDE-aa 940-953 } \\
\text { affinity chromatography }\end{array}$ \\
\hline
\end{tabular}

Darmstadt, Germany) in $\mathrm{H}_{2} \mathrm{O}_{\text {dist }}(20$ min, $\mathrm{RT})$. Subsequent to a 5-min washing step in TBS at RT including buffer change, sections were incubated at $4^{\circ} \mathrm{C}$ overnight with primary antibodies (directed to different epitopes of human IDE, Table I) and diluted in antibody diluent (S2022, Dako, Hamburg, Germany).

The procedure resumed the next day with a 5-min washing step in TBS at RT including buffer change. Then a peroxidase-labeled streptavidin-biotin detection kit (K5003, Dako) was applied, and secondary biotinylated goat-antirabbit/anti-mouse IgG was added to the tissue sections at RT for $30 \mathrm{~min}$. This was followed by a 5-min washing step and a 30-min incubation period with streptavidin-peroxidase at RT as recommended by the manufacturer. After an additional washing step, the chromogenic reaction was carried out by incubating the tissue sections with peroxidase substrate AEC, 3-amino-9-ethylcarbazole, K3464, (Dako) (RT, $10 \mathrm{~min}$ ). After a final washing step, nuclei were counterstained with Mayer's acid hematoxylin solution for $10 \mathrm{sec}$. Finally, the slides were rinsed under running tap water, transferred to $\mathrm{H}_{2} \mathrm{O}_{\text {dist }}$ and mounted with Kaiser's glycerol gelatine (Merck). Stained sections were photographed using a Sony 3CCD colour video camera attached to a Zeiss Axioplan 2 microscope and employing the Zeiss AxioVision software 4.5 SP1.

\section{Results}

Tumor cell lines. To analyze the expression of IDE in various human normal and malignant tissues as well as in several human tumor cell lines of different tissue origin, we utilized four antibodies raised against different epitopes of the target molecule (Table I). As demonstrated by immunoblotting (Fig. 1), two of the antibodies employed (polyclonal antibody UCG 43/6 to ${ }^{6} \mathrm{His}$-tagged full length IDE and polyclonal antibody \#PRB-282C to recombinant IDE-GST-fusion protein containing aa 97-273 of rat IDE) but neither monoclonal antibody \#MMS-282R to human erythrocyte IDE nor polyclonal antibody to peptide p15 (aa 940-953 of rat IDE) detected IDE at the expected position of $\sim 110 \mathrm{kDa}$.

Concerning the cell lines assessed (Caco-2, SK-BR-3, FaDu, HT-1080, CAL 27, U-937, OVMZ-6, HeLa, HaCaT) (Fig. 2),

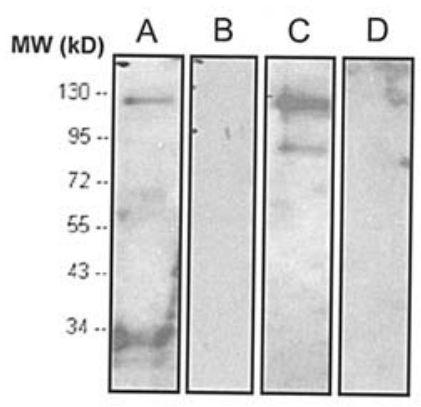

Figure 1. Reaction pattern (Western blot) of ${ }^{6}$ His-tagged full-length IDE protein with four different antibodies to IDE. (A) Rabbit antibody UCG 43/6, (B) mouse antibody \#MMS-282R, (C) rabbit antibody \#PRB-282C and (D) rabbit antibody to IDE-peptide p15.

three of the antibodies, but not anti-p15-IDE, interacted with the main IDE-band whereas, for some of the cell lines, anti15-IDE reacted with polypeptide bands located at $\sim 90 \mathrm{kDa}$ or at lower molecular weight positions (Fig. 2D). Additional polypeptide bands other than the main IDE-protein were also detected by antibody UCG 43/6 and antibody \#PRB-282C, the two staining a prominent band at $\sim 80 \mathrm{kDa}$ (Fig. 2A and C). However, the monoclonal mouse \#MMS-282R antibody, generated against IDE purified from human erythrocytes, detected very specifically the $110-\mathrm{kDa}$ IDE band only, in the cell lines tested (Fig. 2B), not showing any reaction with other IDE-originating polypeptide bands.

Protein expression of IDE was also verified by immunohistochemical staining, employing the same four antibodies directed to IDE (Fig. 3). IDE protein was detected by each of the antibodies in each of the cell lines tested, irrespective of their Western blot reaction pattern, but with a different degree of intensity. IDE is predominantly localized to the cytoplasmic portion of the cells. We noted that antibodies \#MMS-282R and \#PRB-282C were also cross-reacting with artificial-clot elements, consisting of fibrin(ogen), casein, and thrombin (Fig. 3B and C). Such cross-reactions were not noted for the other two IDE-directed antibodies (Fig. 3A and D). Omission of the primary antibody yielded no staining results (data not shown). 
A

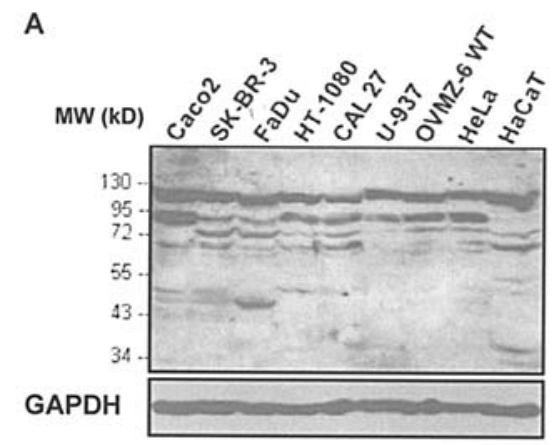

C

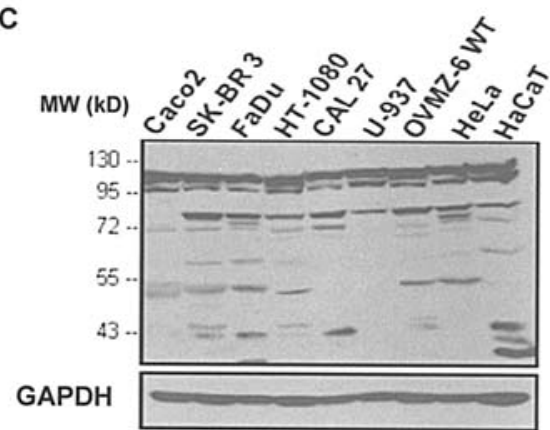

B

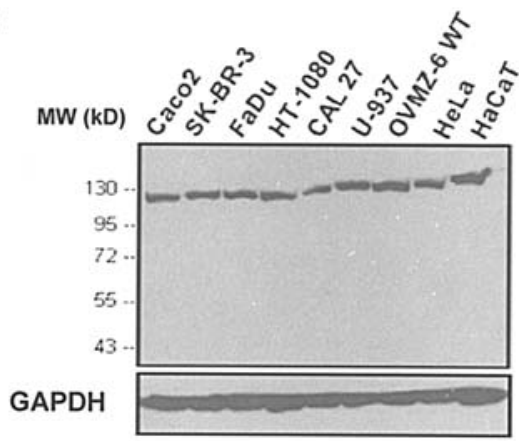

D

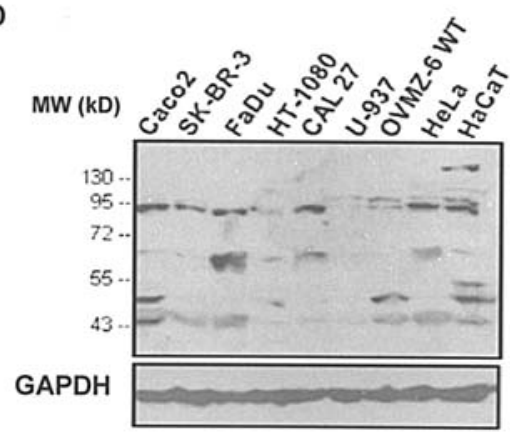

Figure 2. Western blot analysis of IDE protein in detergent extracts obtained from various cell lines applying different antibodies to IDE. Expression patterns of IDE protein in cell extracts visualized by four different antibodies: (A) Rabbit antibody UCG 43/6, (B) mouse antibody \#MMS-282R, (C) rabbit antibody \#PRB-282C and (D) rabbit antibody to IDE-peptide p15. GAPDH (38 kDa) was used as an internal control (bottom line).

Normal tissues. As with the tumor cell lines tested (Figs. 2 and 3), IDE protein was found to be expressed in a variety of normal human tissues (e.g. kidney, liver, lung, brain, skeletal muscle, breast) (Figs. 4 and 5). Similar to the cell lines tested by Western blot analysis, antibody \#MMS-282R was detecting the $110 \mathrm{kDa}$ band only while the other three antibodies were, plus additionally detecting polypeptide bands of a lower molecular weight.

Employing the same four antibodies in assessing normal tissues by immunohistochemical staining, IDE protein expression was detected in each of these normal human tissues: liver, kidney, breast, lung, brain, and skeletal muscle (Fig. 5). In the liver, IDE-directed immunoreactivity was confined to hepatocytes; kidney specimens showed staining for IDE in tubular cells and occasionally scattered stromal cells within the glomeruli were stained as well. IDE protein expression was also detected in the duct epithelia of the mammary gland, in the respiratory epithelia of the lung, in ganglions of the brain, and in skeletal muscle. Similar to the tumor cell lines investigated, IDE-directed immunoreactivity

\section{Caco-2}

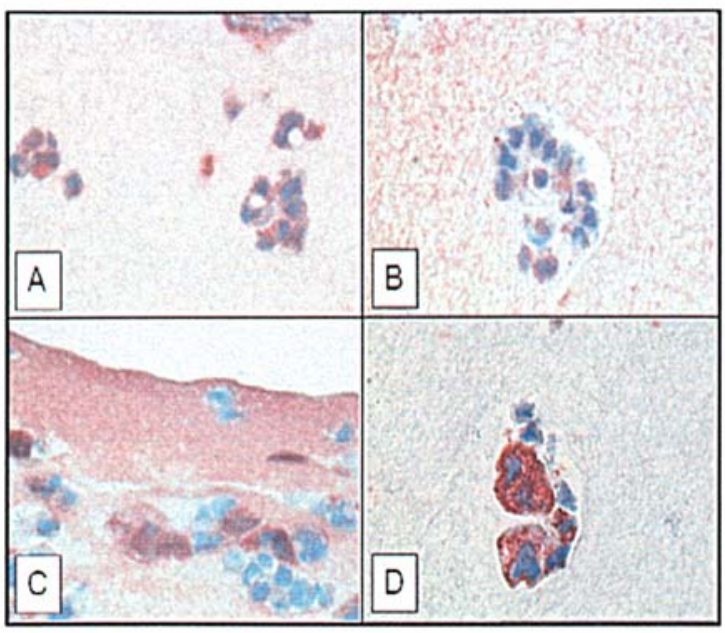

CAL 27

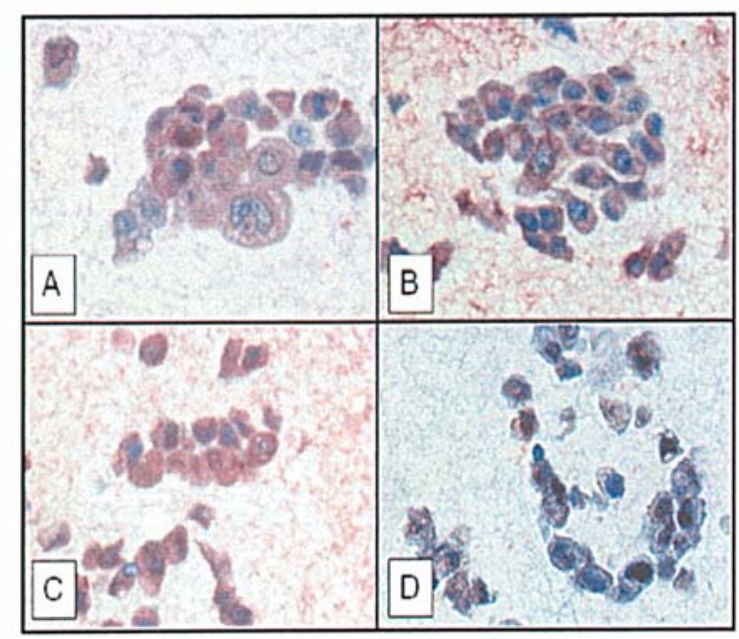


FaDu

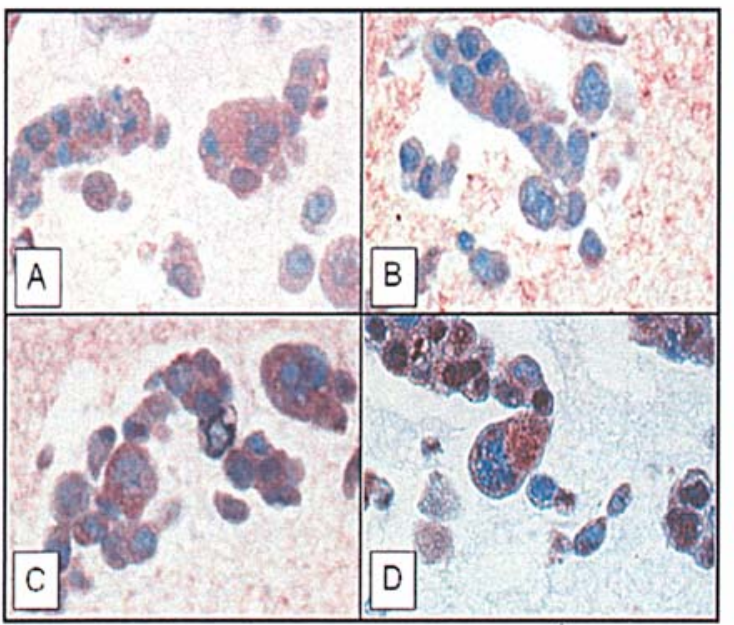

HeLa

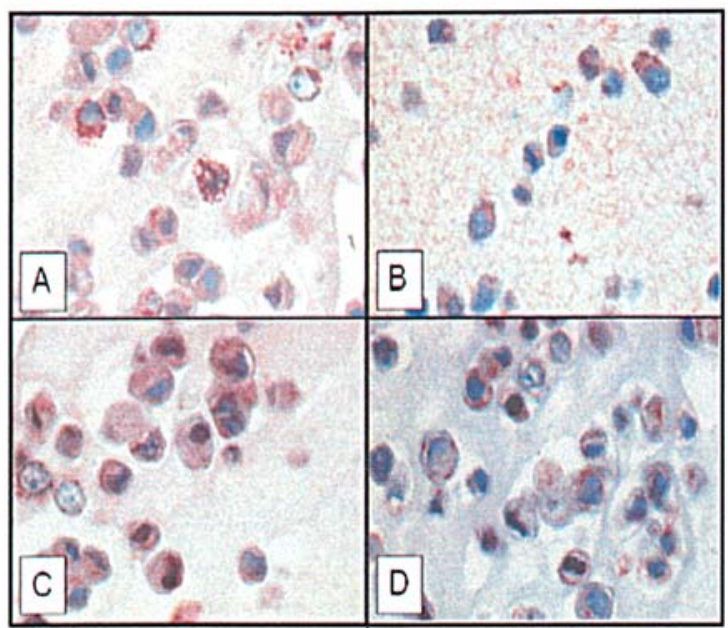

OVMZ-6

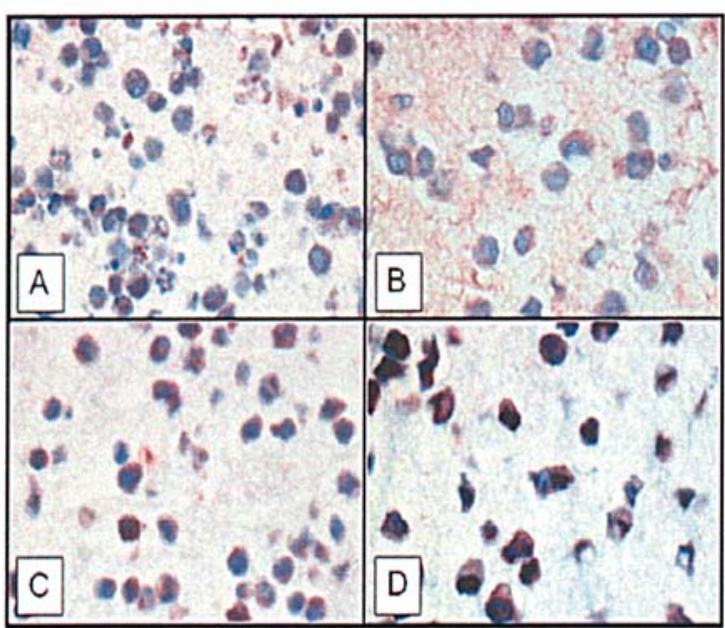

SK-BR-3

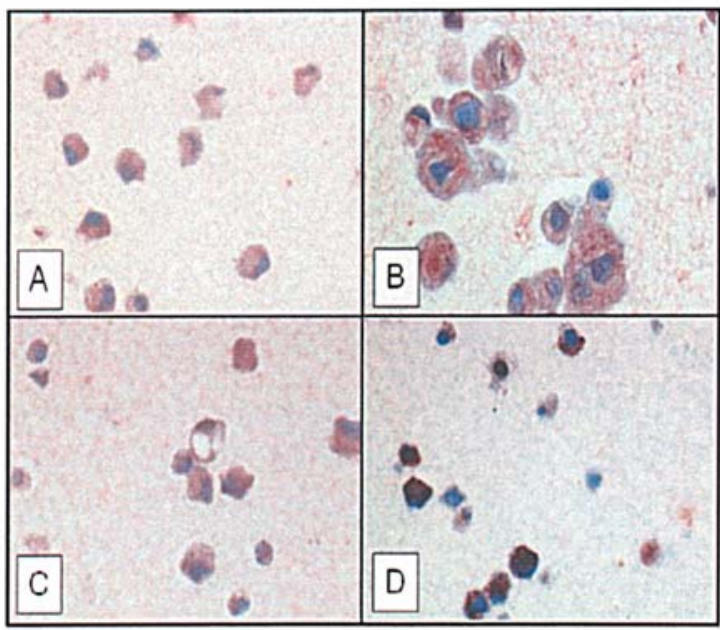

HT-1080

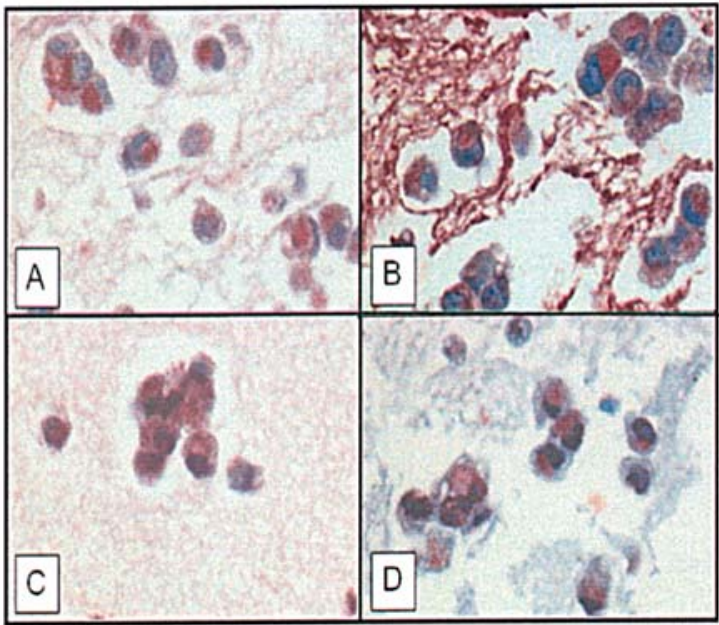

U-937

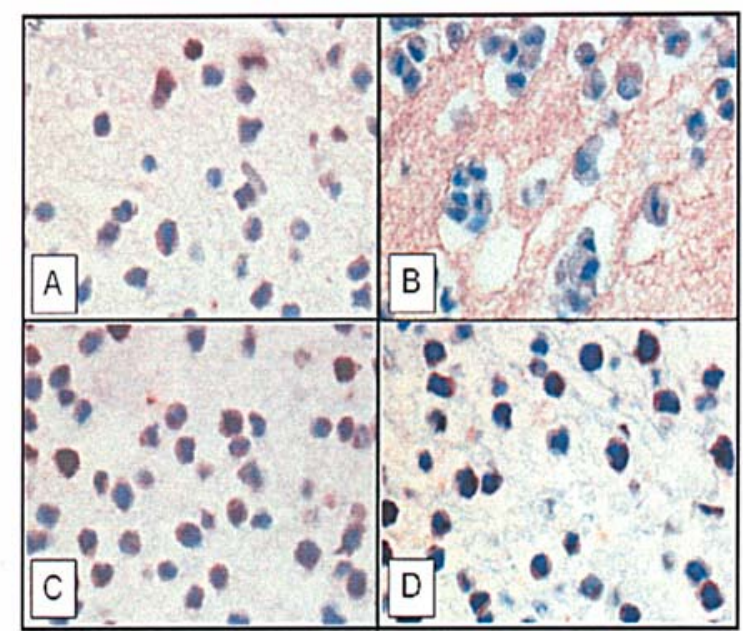

Figure 3. Immunohistochemical localization of IDE protein in paraffin-embedded cell lines applying different antibodies to IDE. (A) Rabbit antibody UCG 43/6, (B) mouse antibody \#MMS-282R, (C) rabbit antibody \#PRB-282C and (D) rabbit antibody to IDE-peptide p15. Red, IDE staining; blue, staining of nuclei. Magnification x400. 
A

A

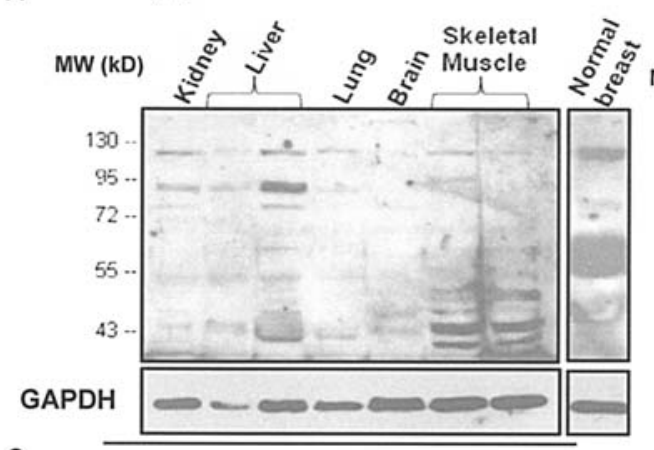

B

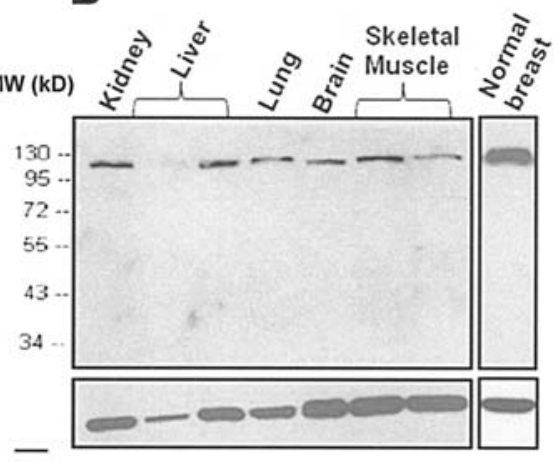

D
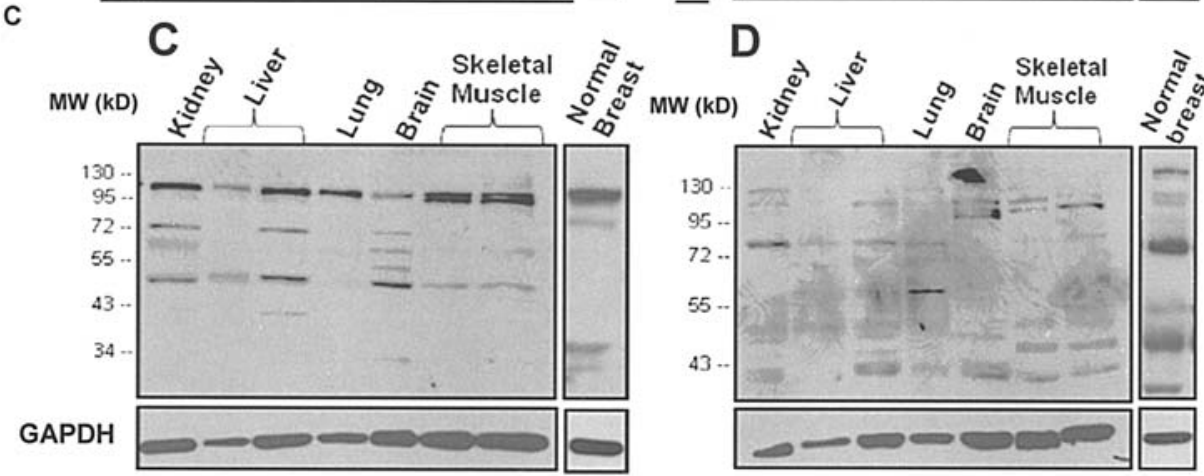

Figure 4. Western blot analysis of IDE protein expression in detergent-released extracts of normal tissues, applying different antibodies to IDE. (A) Rabbit antibody UCG 43/6, (B) mouse antibody \#MMS-282R, (C) rabbit antibody \#PRB-282C and (D) rabbit antibody to IDE-peptide p15. GAPDH (38 kDa) was used as an internal control (bottom line).

was localized to the cytoplasmic compartment. It is worth noting that all four IDE-directed antibodies reacted equally but displayed certain variations in staining intensity. Furthermore, in some tissues (e.g. breast and brain), weak to moderate staining of the extracellular matrix by all four antibodies was observed. Omission of the primary antibody yielded no staining results (data not shown).

Breast and ovarian cancer tissues. Apart from normal human tissues, we extended our investigations on the presence and tissue distribution of IDE protein to breast and ovarian cancer tissues, using Western blot analysis (Figs. 6 and 7) and immunohistochemistry (Fig. 8). Applying the same set of antibodies as previously described, IDE was detected in detergent-extracted breast by Western blotting (Fig. 6). Regarding all nine breast cancer tissue specimens investigated, antibody \#MMS-282R generated to erythrocyte IDE reacted with the $110-\mathrm{kDa}$ IDE band only (Fig. 6B), a pattern observed previously with normal tissues and tumor cell lines. Likewise, rabbit antibody \#PRB-282C reacted with the same IDE-linked $110 \mathrm{kDa}$ band, but also exhibited reaction with lower polypeptide bands, especially at $\sim 50,60$ and $70 \mathrm{kDa}$ (Fig. 6C). Antibody UCG 43/6 also detected the $110 \mathrm{kDa}$ band, but in addition to this, detected a prominent band at $\sim 90 \mathrm{kDa}$ also stained with the antibody (Fig. 6A), which was not present in normal breast tissue extracts (Fig. 4). In contrast to the reaction pattern observed in Fig. 6A and $\mathrm{B}$, anti-IDE-p15 reacted mainly with an $\sim 70 \mathrm{kDa}$ band (Fig. 6D); a band also reactive with antibody \#PRB-282C (Fig. 6C).

Concerning all of the nine ovarian cancer tissue specimens investigated, antibody \#MMS-282R (Fig. 7B) reacted with the $110-\mathrm{kDa}$ IDE band only, a pattern previously observed with normal tissues, tumor cell lines, and breast cancer tissue extracts. Antibody \#PRB-282C also reacted with the 110-kDa band, but in addition reacted with lower polypeptide bands (Fig. 7C) with intense reaction at $\sim 90 \mathrm{kDa}$. Antibody UCG $43 / 6$ also detected the $110-\mathrm{kDa}$ band, but in addition to this, in some cases, a prominent band at $\sim 90 \mathrm{kDa}$ (Fig. 7A), such as in breast cancer extracts was observed. Anti IDE-p15 reacted with two main bands at $\sim 70 \mathrm{kDa}$ (such as in breast cancer) and $\sim 90 \mathrm{kDa}$ (Fig. 7D).

Regarding IDE protein expression in breast cancer (Fig. 8, upper panel) as assessed by immunohistochemical staining applying the four different IDE-directed antibodies, as in normal breast ductal epithelium, IDE protein was expressed in epithelial cells with scattered abundance in non-tumor cells present in the extracellular matrix, confirming our initial observation reported by Radulescu et al (30). Similar to epithelial cells in ducts of the normal breast, IDE was found in the cytosolic part of the tumor cells, with heterogeneous expression, as shown for all of the four antibodies applied. Although different polypeptide bands were stained with the antibodies when analyzing tumor tissue extracts by immunoblotting (Fig. 6), no qualitative differences were observed regarding the various antibodies and the resulting staining patterns (Fig. 8, upper panel). Similar findings were obtained when assessing ovarian cancer tumor tissue specimens (Figs. 7 and 8 lower panel).

\section{Discussion}

Expression and function of the metalloprotease insulindegrading enzyme (IDE), an enzyme known to be involved in 


\section{Liver}

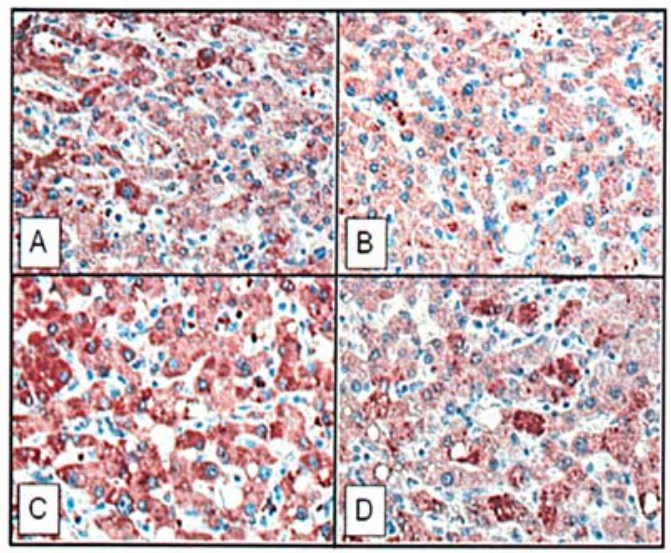

Breast

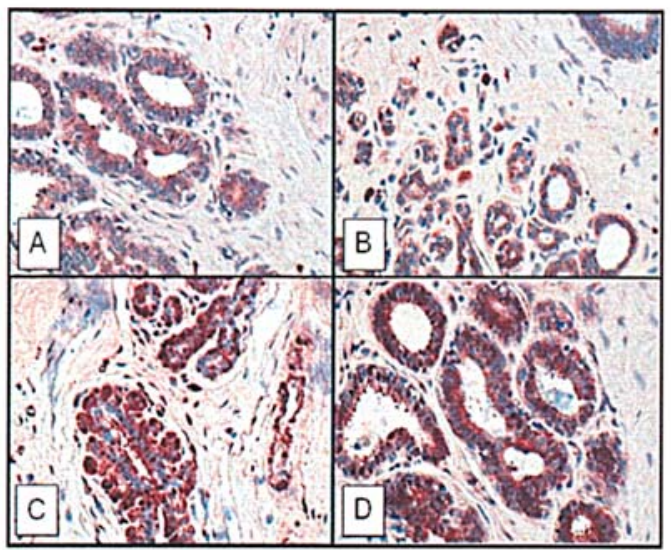

Brain

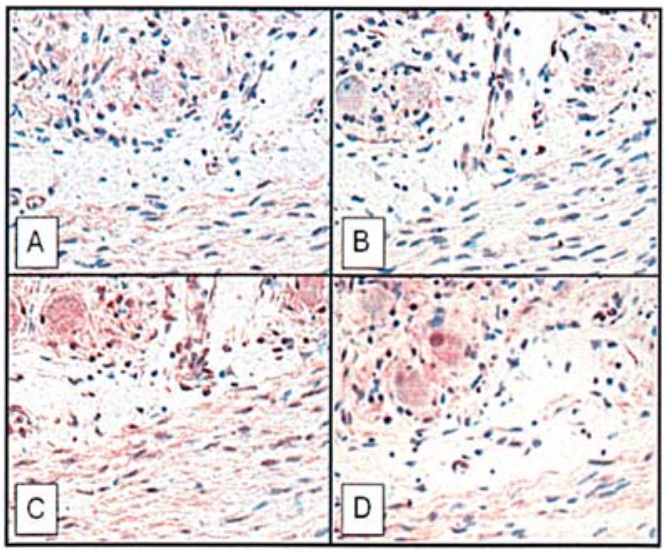

Kidney

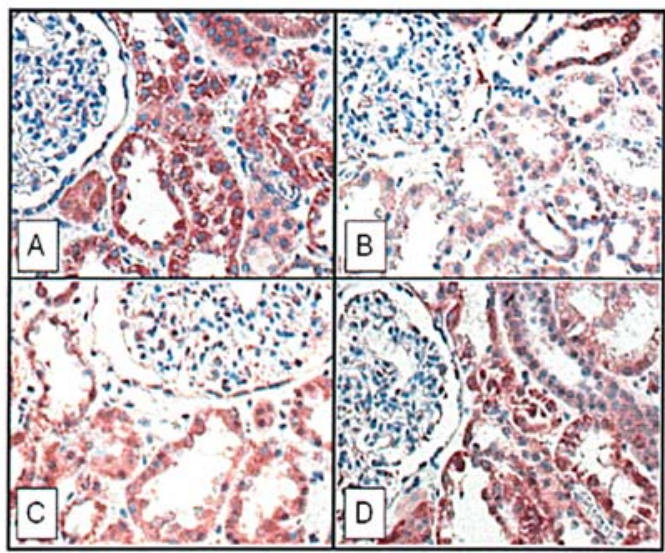

Lung

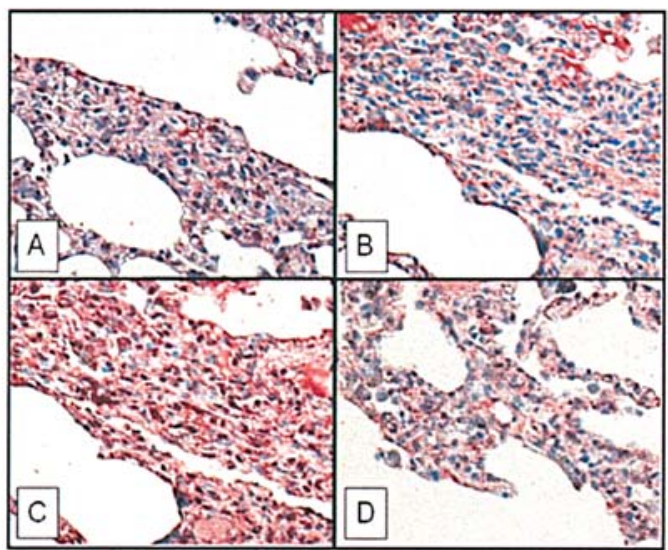

Skeletal muscle

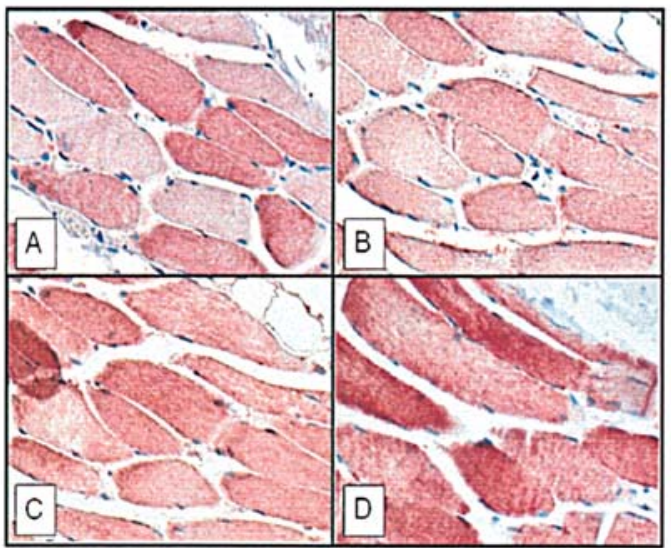

Figure 5. Immunohistochemical visualization of cytosolic IDE protein in paraffin-embedded human normal tissues applying different antibodies to IDE. (A) Rabbit antibody UCG 43/6, (B) mouse antibody \#MMS-282R, (C) rabbit antibody \#PRB-282C and (D) rabbit antibody to IDE-peptide p15. Red, IDE staining; blue, staining of nuclei. Magnification x200.

the degradation of neurotoxic amyloid peptides and insulin, is usually impaired in Alzheimer's disease and diabetes (27-29,35). However, reports about its involvement in malignancy are scarce $(25,30,36)$. IDE was initially purified from human red blood cells (37) but is also present in a wide range of nucleated cells (www.genecards.org/cgi-bin/carddisp.pl?gene=IDE). Depending on the type of cell, IDE may be located in the cytosol $(38,39)$, peroxisomes $(13,40)$, endosomes $(12,41)$, mitochondria (15), or on the cell membrane $(7-11,42)$.

Particularly, after binding to its plasma membrane receptor, insulin succeeds internalization into the cell (43), where it is released from endosomes into the cytosol and follows its pathway to the nucleus. IDE is found to be mostly active in the cytosol, therefore it appears to take part in the regulation of 

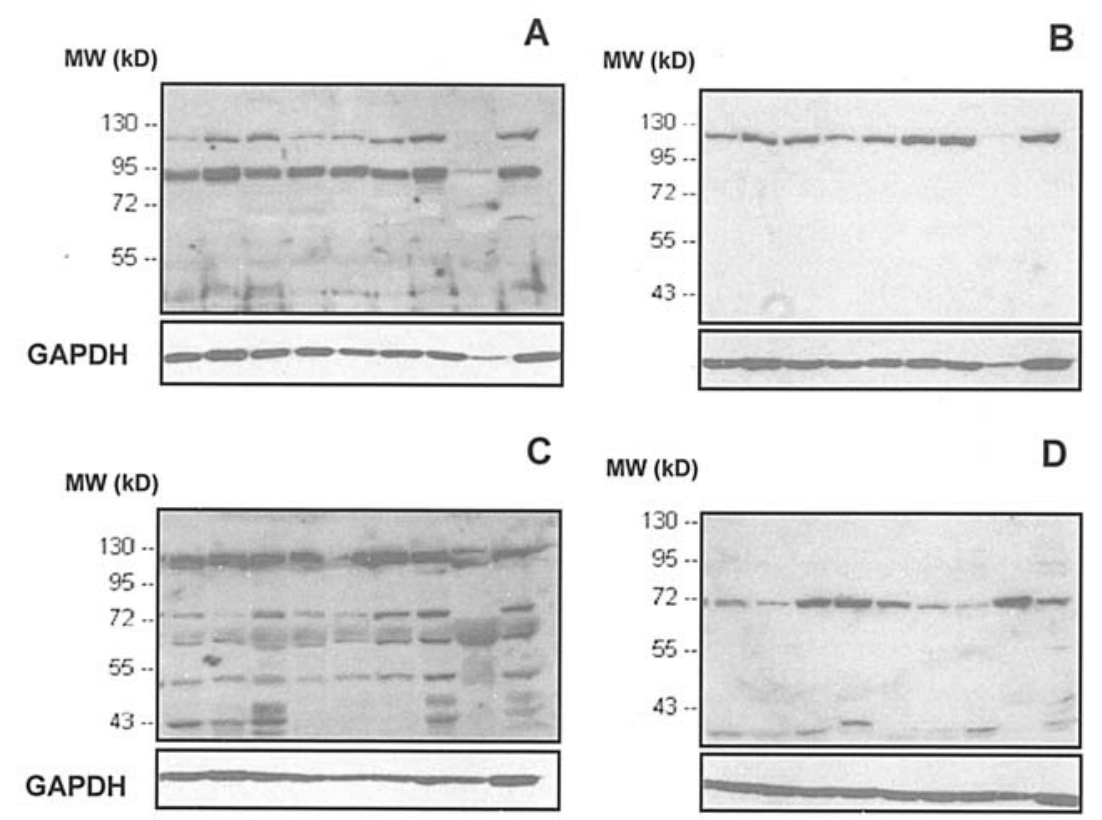

Figure 6. Western blot analysis of IDE protein expression in detergent-released extracts of breast cancer tumor tissues (n=9) applying different antibodies to IDE. (A) Rabbit antibody UCG 43/6, (B) mouse antibody \#MMS-282R, (C) rabbit antibody \#PRB-282C and (D) rabbit antibody to IDE-peptide p15. GAPDH (38 kDa) was used as an internal control (bottom line).

A

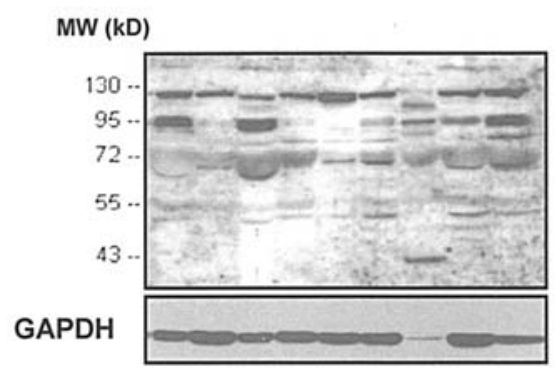

B

MW (kD)

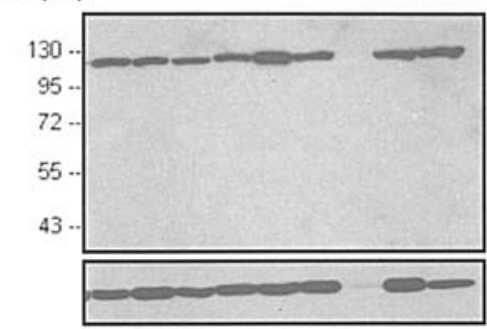

$C_{\text {MW }(\mathrm{kD})}$

D

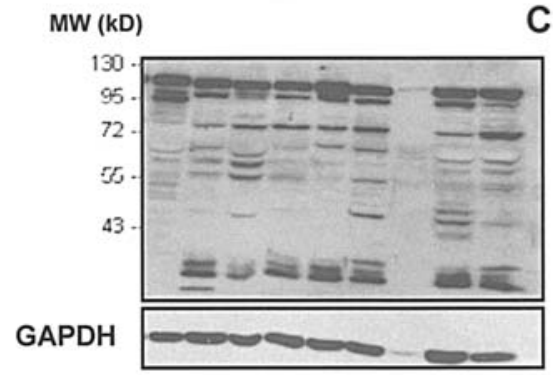

D 

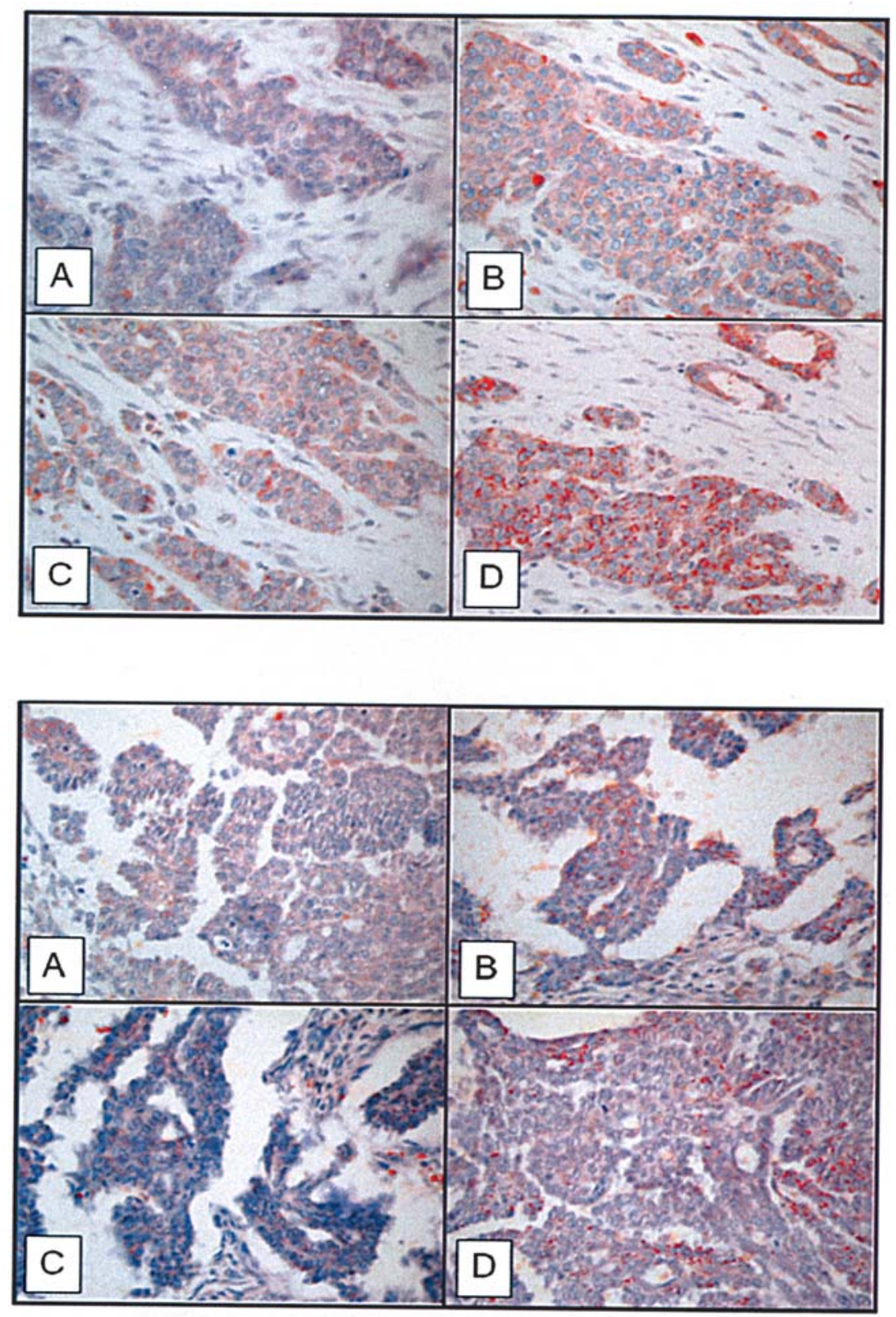

Figure 8. IDE protein expression in breast (upper panel) and ovarian cancer (lower panel) tissue specimens applying different antibodies to IDE. (Magnification x400). (A) Rabbit antibody UCG 43/6, (B) mouse antibody \#MMS-282R, (C) rabbit antibody \#PRB-282C and (D) rabbit antibody to IDEpeptide p15.

different tissue origin by immunoblotting, such as SK-BR-3, FaDu, HT-1080, CAL 27, U-937, OVMZ-6, HeLa and HaCaT, by employing four different antibodies generated against different epitopes of the enzyme. Regarding these cell lines, all four antibodies displayed different patterns of IDE expression, whereby antibody \#MMS-282R, generated by immunizing mice with purified IDE enriched from human erythrocytes, was only reactive with the prominent $110-\mathrm{kDa}$ band. Notably, anti-IDE-p15 did not detect the 110-kDa band but instead an $\sim 90 \mathrm{kDa}$ band, although it was described previously to recognize full length IDE extracted from rat tissue $(48,49)$. Antibody UCG $43 / 6$ directed to full length IDE also detected this IDE band, plus a variety of other bands in the low molecular weight range. Still, at the light microscopic level, all of the antibodies examined did localize IDE to the cytoplasm of the tumor cell lines investigated.
This feature was also observed in healthy and diseased tissues. As demonstrated by Western blot analysis and immunohistochemistry, tissues such as kidney and liver, which comprise the primary sites of insulin clearance, or skeletal muscle, an insulin-sensitive tissue, expressed IDE, as did other types of tissues (lung, brain, breast). In accordance with our previous results (30), we showed expression of IDE in tumor cells of breast cancer tissue. By extending these findings, we demonstrated that IDE is also present in tumor cells in ovarian cancer tissue.

Acknowledging the fact that this is an initial wideranging study reporting the expression of IDE on the background of malignancy, it is possible to speculate about a regulatory role of IDE in tumor progression and metastasis. To prove this, functional in vitro and vivo tests will have to be performed at molecular and cellular levels. 


\section{Acknowledgements}

This work was supported by a grant endowed to M. Schmitt and C. Giersig by the Federal Institute for Drugs and Medical Devices (BfArM), Bonn. The authors thank Daniela Hellmann for the expert technical assistance.

\section{References}

1. Fawcett J, Permana PA, Levy JL and Duckworth WC: Regulation of protein degradation by insulin-degrading enzyme: analysis by small interfering RNA-mediated gene silencing. Arch Biochem Biophys 468: 128-133, 2007.

2. Rawlings ND, Morton FR, Kok CY, Kong J and Barrett AJ: MEROPS: the peptidase database. Nucleic Acids Res 36: D320-D325, 2008.

3. Mirsky IA and Broth-Kahn RH: The inactivation of insulin by tissue extracts. I. The distribution and properties of insulin inactivating extracts (insulinase). Arch Biochem 20: 1-9, 1949.

4. Duckworth WC: Insulin degradation: mechanisms, products, and significance. Endocr Rev 9: 319-345, 1988.

5. Duckworth WC: Insulin degrading enzyme. In: Insulin Cuatrecasas P and Jacobs S (eds). Springer-Verlag, Berlin, 1990.

6. Duckworth WC, Bennett RG and Hamel FG: Insulin degradation: progress and potential. Endocr Rev 19: 608-624, 1998.

7. Duckworth WC: Insulin and glucagons binding and degradation by the kidney cell membrane. Endocrinology 102: 1766-1774, 1978.

8. Duckworth WC: Insulin degradation by liver cell membranes. Endocrinology 104: 1758-1764, 1979.

9. Yokono K, Imamura Y, Sakai H and Baba S: Insulin degrading activity of plasma membranes from rat skeletal muscle: its isolation, characterization, and biologic significance. Diabetes 28: 810-817, 1979.

10. Yokono K, Roth RA and Baba S: Identification of insulindegrading enzyme on the surface of cultured human lymphocytes, rat hepatoma cells, and primary cultures of rat hepatocytes. Endocrinology 111: 1102-1108, 1982.

11. Goldfine ID, Williams JA, Bailey AC, Wong KY, Iwamoto Y, Yokono K, Baba S and Roth RA: Degradation of insulin by isolated mouse pancreatic acini: evidence for cell surface protease activity. Diabetes 33: 64-72, 1984.

12. Hamel FG, Mahoney MJ and Duckworth WC: Degradation of intraendosomal insulin by insulin degrading enzyme without acidification. Diabetes 40: 436-443, 1991.

13. Authier F, Bergeron JJ, Ou WJ, Rachubinski RA, Posner BI and Walton PA: Degradation of the cleaved leader peptide of thiolase by a peroxisomal proteinase. Proc Natl Acad Sci USA 92: 3859-3863, 1995.

14. Rabkin R, Birn H, Shi J, Roth R and Christensen E: Insulin degrading enzyme (IDE) in renal proximal tubules. Diabetes 41: $15 \mathrm{~A}, 1992$.

15. Leissring MA, Farris W, Wu X, Christodoulou DC, Haigis MC Guarente L and Selkoe DJ: Alternative translation initiation generates a novel isoform of insulin-degrading enzyme targeted to mitochondria. Biochem J 383: 439-446, 2004.

16. Authier F, Posner BI and Bergeron JJM: Insulin-degrading enzyme. Clin Invest Med 19: 149-160, 1996.

17. Kurochkin IV: Amyloidogenic determinant as a substrate recognition motif of insulin-degrading enzyme. FEBS Lett 427: 153-156, 1998

18. Bennett RG, Duckworth WC and Hamel FG: Degradation of amylin by insulin-degrading enzyme. J Biol Chem 275: 36621-36625, 2000 .

19. Kurochkin IV: Insulin-degrading enzyme: embarking on amyloid destruction. Trends Biochem Sci 26: 421-425, 2001.

20. Valera Mora ME, Scarfone A, Calvani M, Greco AV and Mingrone G: Insulin clearance in obesity. J Am Coll Nutr 22: 487-493, 2003.

21. Bennett RG, Hamel FG and Duckworth WC: Characterization of the insulin inhibition of the peptidolytic activities of the insulindegrading enzyme-proteasome complex. Diabetes 46: 197-203, 1997.

22. Gehm BD and Rosner MR: Regulation of insulin, epidermal growth factor, and transforming growth factor- $\alpha$ levels by growth factor-degrading enzymes. Endocrinology 128: 1603-1610, 1991.
23. Hamel FG, Gehm BD, Rosner MR and Duckworth WC: Identification of the cleavage sites of transforming growth factor alpha by insulin-degrading enzymes. Biochim Biophys Acta 1338: 207-214, 1997.

24. Farris W, Mansourian S, Chang Y, Lindsley L, Eckman EA, Frosch MP, Eckman CB, Tanzi RE, Selkoe DJ and Guenette S: Insulin-degrading enzyme regulates the levels of insulin, amyloid beta-protein, and the beta-amyloid precursor protein intracellular domain in vivo. Proc Natl Acad Sci USA 100: 4162-4167, 2003.

25. Harada S, Smith RM, Smith JA and Jarett L: Inhibition of insulin-degrading enzyme increases translocation of insulin to the nucleus in $\mathrm{H} 35$ rat hepatoma cells - evidence of a cytosolic pathway. Endocrinology 132: 2293-2298, 1993.

26. Radulescu RT, Doklea ED, Kehe K and Mückter H: Nuclear colocalization and complex formation of insulin with retinoblastoma protein in HepG2 human hepatoma cells. J Endocrinol 166: R1-R4, 2000.

27. Sladek R, Rocheleau G, Rung J, Dina C, Shen L, Serre D, Boutin P, Vincent D, Belisle A, Hadjadj S, Balkau B, Heude B, Charpentier G, Hudson TJ, Montpetit A, Pshezhetsky AV, Prentki M, Posner BI, Balding DJ, Meyre D, Polychronakos C and Froguel P: A genome-wide association study identifies novel risk loci for type 2 diabetes. Nature 445: 881-885, 2007.

28. Kwak SH, Cho YM, Moon MK, Kim JH, Park BL, Cheong HS, Shin HD, Jang HC, Kim SY, Lee HK and Park KS: Association of polymorphisms in the insulin-degrading enzyme gene with type 2 diabetes in the Korean population. Diabetes Res Clin Pract 79: 284-290, 2008.

29. Bertram L, McQueen MB, Mullin K, Blacker D and Tanzi RE: Systematic meta-analyses of Alzheimer disease genetic association studies: the AlzGene database. Nat Genet 39: 1723,2007

30. Radulescu RT, Hufnagel C, Luppa P, Hellebrand H, Kuo WL, Rosner MR, Harbeck N, Giersig C, Meindl A, Schmitt M and Weirich G: Immunohistochemical demonstration of the zinc metalloprotease insulin-degrading enzyme in normal and malignant human breast: Correlation with tissue insulin levels. Int J Oncol 30: 73-80, 2007.

31. Simon R, Mirlacher M and Sauter G: Tissue microarrays in cancer diagnosis. Expert Rev Mol Diagn 3: 421-430, 2003.

32. Schmitt M, Mengele K, Schueren E, Sweep FC, Foekens JA, Brünner N, Laabs J, Malik A and Harbeck N: European Organisation for Research and Treatment of Cancer (EORTC) Pathobiology Group standard operating procedure for the preparation of human tumour tissue extracts suited for the quantitative analysis of tissue-associated biomarkers. Eur J Cancer 43: 835-844, 2007.

33. Shen Y, Joachimiak A, Rosner MR and Tang WJ: Structures of human insulin-degrading enzyme reveal a new substrate recognition mechanism. Nature 443: 870-874, 2006.

34. Chesneau V and Rosner MR: Functional human insulindegrading enzyme can be expressed in bacteria. Protein Expr Purif 19: $91-98,2000$.

35. Sun MK and Alkon DL: Links between Alzheimer's disease and diabetes. Drugs Today 42: 481-489, 2006.

36. Chang LL, Stout LE, Wong WD, Buls JG, Rothenberger DA, Shier WT, Sorenson RL and Bai JP: Immunohistochemical localization of insulin-degrading enzyme along the rat intestine, in the human colon adenocarcinoma cell line (Caco-2), and in human ileum. J Pharm Sci 86: 116-119, 1997.

37. Shii K, Yokono K, Baba S and Roth RA: Purification and characterization of insulin-degrading enzyme from human erythrocytes. Diabetes 35: 675-683, 1986.

38. Schmitz A, Schneider A, Kummer MP and Herzog V: Endoplasmic reticulum-localized amyloid beta-peptide is degraded in the cytosol by two distinct degradation pathways. Traffic 5: 89-101, 2004

39. Bai JP, Hong HJ, Rothenberger DA, Wong WD and Buls JG: The presence of insulin-degrading enzyme in human ileal and colonic mucosal cells. J Pharm Pharmacol 48: 1180-1184, 1996.

40. Morita M, Kurochkin IV, Motojima K, Goto S, Takano T, Okamura S, Sato R, Yokota S and Imanaka T: Insulin-degrading enzyme exists inside of rat liver peroxisomes and degrades oxidized proteins. Cell Struct Funct 25: 309-315, 2000.

41. Duckworth WC and Hamel FG: Cellular and endosomal insulin degradation. Adv Second Messenger Phosphoprotein Res 24: 521-528, 1990 . 
42. Lynch JA, George AM, Eisenhauer PB, Conn K, Gao W, Carreras I, Wells JM, McKee A, Ullman MD *and Fine RE: Insulin degrading enzyme is localized predominantly at the cell surface of polarized and unpolarized human cerebrovascular endothelial cell cultures. J Neurosci Res 83: 1262-1270, 2006.

43. Exton JH: Some thoughts on the mechanism of action of insulin. Diabetes 40: 521-526, 1991.

44. O'Brien RM and Granner DK: Regulation of gene expression by insulin. Biochem J 278: 609-619, 1991.

45. Bertram L, Blacker D, Mullin K, Keeney D, Jones J, Basu S, Yhu S, McInnis MG, Go RC, Vekrellis K, Selkoe DJ, Saunders AJ and Tanzi RE: Evidence for genetic linkage of Alzheimer's disease to chromosome 10q. Science 290: 2302-2303, 2000.

46. Fakhrai-Rad H, Nikoshkov A, Kamel A, Fernström M, Zierath JR, Norgren S, Luthman H and Galli J: Insulin-degrading enzyme identified as a candidate diabetes susceptibility gene in GK rats. Hum Mol Genet 9: 2149-2158, 2000.
47. Bai JP, Hsu MJ and Shier WT: Insulin-degrading enzyme in a human colon adenocarcinoma cell line (Caco-2). Pharm Res 12: 513-517, 1995.

48. Camberos MC, Pérez AA, Udrisar DP, Wanderley MI and Cresto JC: ATP inhibits insulin-degrading enzyme activity. Exp Biol Med 226: 334-341, 2001.

49 Udrisar DP, Wanderley MI, Porto RC, Cardoso CL, Barbosa MC, Camberos MC and Cresto JC: Androgen- and estrogen-dependent regulation of insulin-degrading enzyme in subcellular fractions of rat prostate and uterus. Exp Biol Med 230: 479-486, 2005. 